\title{
The effect of age on fibre digestion in the rabbit
}

\author{
I. G. PARTRIDGE
}

The Rowett Research Institute, Bucksburn, Aberdeen $A B 29 S B$

(Great Britain)

The ability of the commerclal meat rabbit to digest dietary fibre was examined at three different ages ( 6 weeks, I 4 weeks and 22 weeks). Dried grassmeal provided the principal fibre source in two experimental diets fed ad libitum. The ADF content of the diets was I3० $\mathrm{g}$ ADF $/ \mathrm{kg}$ $\mathrm{DM}$ (diet A) and $226 \mathrm{~g} \mathrm{ADF} / \mathrm{kg}$ (diet B).

There was no apparent improvement in the DM digestibility of either diet as the animal aged. Overall the DM digestibility coefficients for diet A and diet B were $7 \mathrm{I}$ p. Ioo and $54 \mathrm{p}$. I oo respectively. Similarly there was no improvement in ADF digestibility with age, coefficients of ADF digestibility being on average $13 \mathrm{p}$. roo (diet A) and 12 p. roo (diet B). Animals fed continuously on the high fibre diet did not consistently digest more fibre than those animals changed from the low to high fibre diet for the duration of each balance period, i.e. there was no evidence of animals adapting their fibre digesting capabilities. The low fibre digestibilities reported could be associated with the degree of lignification of these grassmeal-based diets (approx. 22 p. Ioo of the ADF fraction).

\section{Effect of different crude fibre levels on nutrient digestibility of diets for growing rabbits}

\author{
R. DESSIMONI CARREGAL and C. F. ZINSLY \\ Faculdade de Ciencias Agrarias e Veterinarias "Campus * de Jaboticabal \\ UNESP - Dept. de Producao Animal. Rod. Carlos Tonanni s/n. Jaboticabal-SP
}

(Brazil)

The work was made at the Rabbit culture Section of Faculdade de Medicina Veterinaria e Agronomia de Jaboticabal, with the aim to observe the effect of different crude fibre levels on the nutrient digestibility of growing rabbits as well as to estimate the digestion capacity of the fibrous fraction of the diet.

The trials were made with 15 New Zealand white rabbits using diets containing 7 , Io and I 3 p. roo crude fibre and the experiment was achieved with 5 replications entirely at random.

The following conclusions were drawn: I - the digestibility coefficient of organic matter, protein and non nitrogenous extract reduced with increasing levels of crude fibre in the diet. 2 - Rise in the crude fibre levels of the diet increased its digestibility coefficients. This increase was probably due to the analytical method used.

\section{Energy feeding of rabbits with low cost and high fibre materials}

\author{
J. M. CID DIAZ
}

Antonio Lopez 5I, Madrid, 29 (Spain)

Eight New-Zealand doe rabbits ( 8 month-old) and young rabbits of 2 nd parturition were fed diets at two energy levels using low cost feeds without lucerne $(2900$ kcal digestible energy (DE) per $\mathrm{kg}$ feed and $2625 \mathrm{kcal} \mathrm{DE} / \mathrm{kg}$ for doe-rabbits and 2835 to 3 I $50 \mathrm{kcal} / \mathrm{kg}$ feed for their 
youngs). We studied the feeding effects on the number of young rabbits at birth and their performance at 70 days of age.

From the obtained information, we conclude that:

- doe-rabbits showed a racial heterogeneity which had an effect on production process;

- it is necessary to have a better bromatology knowledge of fibrous materials for a better use in rabbit feeding having regard to their low cost;

- Feed for rabbits with high energy levels (DE) gives better results; the 3 I50 kcal digestible Energy $/ \mathrm{kg}$ when adding fat are equivalent to $3000 \mathrm{kcal}$ metabolisable Energy $/ \mathrm{kg}$.

- In experimental rooms of small research units with controlled environment, we must use purebred or high level selected rabbits;

- When using fibrous materials in rabbit feeding, attention has to be paid to technological aspects, feed palatability and addition of synthesis amino-acids.

\title{
Energy and digestible protein concentration of diets Effects on growth performances of rabbits
}

\author{
Chantal DEHALIE \\ Laboratoire de Recherohes sur l'Élevage du Lapin, I.N.R.A. \\ B.P. $12-31320$ Castanet Tolosan (France)
}

Sixty 5 week-old rabbits of both sexes were offered 4 diets with a digestible energy value of $2320 \mathrm{kcal} / \mathrm{kg}$ or $2730 \mathrm{kcal} / \mathrm{kg}$ and 49.4 or $58.3 \mathrm{~g}$ digestible protein per $\mathrm{I}$ ooo $\mathrm{kcal}$ digestible energy. At the end of the 5 week experimental period the animals were slaughtered to determine the energy and protein balances. The apparent digestibility was studied during the third experimental week. Replacement of starch by straw decreased the digestible energy content of the diets. But, protein digestibility of thedifferent diets was not affected. When the digestible energy concentrations in the diets decreased, the animals kept their daily digestible energy intake fairly constant and maintained their growth rate. The digestible proteins/digestible energy ratio did not significantly affect either the apparent digestibility of the different nutrients, or the growth performances. The efficiency of protein deposition was higher when the digestible protein digestible energy ratio was low.

\section{Effects of dietary metabolisable energy concentration and physical form of the diet on the performance of growing rabbits}

\author{
D. H. MACHIN ( ${ }^{(1)}$, Catherine BUTCHER ( ${ }^{(2)}$, E. OWEN $\left({ }^{(2)}\right.$, M. BRYANT ( ${ }^{(3)}$, J. E. OWEN
}

(1) Tropical Products Institute, 56-62 Grays Inn Road, London WCIX 8 LU (United Kingdom).

(2) Reading University, Department of A griculture and Horticulture, Earley Gate, Reading RG6 $2 A T$ (United Kingdom).

This study was carried out to assess the ability of rabbits to use diets of various nutrient density and form.

In this study, 24 seven week old Californian rabbits (initial weight I.44 $\pm 0.33 \mathrm{~kg}$ ) were pair-fed 2 diets in 3 physical forms. The 2 diets $(8 \mathrm{M} / \mathrm{D}$ and I $2 \mathrm{M} / \mathrm{D}$ ) were formulated to contain 8 and $\mathrm{I} 2 \mathrm{MJ} / \mathrm{kg}$ dry matter using ruminant metabolisable energy values. Crude protein content was $160 \mathrm{~g} / \mathrm{kg}$ dry matter. Ground barley straw was the main fibre source. Diets were 